process of Enlightenment, with the Reformation a backdrop, not a static set of parameters, to fight over these new directions. Therefore, theological polemic did not damn England to Leviathan mastery but reflected the Church of England's complex, though continuous, complicity in growing the beast. In contrast, English Protestants were not locked into creating a Hobbesian state, and historicizing theology did not create a secular totem. Instead, the strange career of a Henry Dodwell could offer an alternative path on the practice of history and the development of Leviathan.

J.C. Parks

Lehigh University

\title{
Paul R. D. Lawrie, Forging A Laboring Race: The African American Worker in the Progressive Imagination (New York: NYU Press, 2016). 256 pp. Soft- cover $\$ 50.00$.
}

In Forging a Laboring Race: The African American Worker in the Progressive Imagination Lawrie sets out to explore how "black proletarianization was mediated through the state and how progressives came to understand these processes in deeply corporeal terms" (5). Lawrie examines government documents, industry records, and the personal papers of Progressive-era authors, academics, and reformers to effectively paint a sobering picture of how race science and eugenics, rationalized labour management, social services, and segregationist impulses coalesced around an imagined black body to reinforce, augment, and repeatedly recreate nineteenth and twentieth-century "Negro Problems."

Lawrie's account prioritizes the social and economic dynamics of the First World War, as well as broader public concerns. He not only highlights the pivot from black sharecropping and the beginnings of black industrial labour, but also the anxieties regarding African Americans' role on the domestic front, in military service, and, at the conflict's end, their place within the nation. Documents from three governmental bodies make up the bulk of Lawrie's sources here: the Department of Negro Economics (DNE), which drew upon Chicago School sociology to attempt to integrate black labourers into the wartime economy; the Committee on Anthropology (COA), which examined the first million U.S. army recruits, a mixed-race workforce at a shipbuilding site in Philadelphia, and 100,000 demobilized men at war's end to evaluate the health of the "Negro type" and link race, soldiering, and working to the wartime state; and the Federal Board of Vocational Education (FBVE), tasked with rehabilitating disabled black veterans. In fact, Lawrie helpfully builds upon the work of Katherine Kudlick, Barbara Young Welke, and others who view bodily ability as key to regimes of citizenship.

Lawrie examines several figures, like Frederick Hoffman and Lothrop 
Stoddard, whose work historians often associate with the ideologies of white supremacy. But Lawrie sheds new light on these men, as well as lesser-known individuals, by linking their theories to the birth of discriminatory insurance policies, African American transition from bonded to factory labour, and immigration restrictions borne of a racialized body politic.

Lawrie boldly claims in his introduction that Progressive theories about the black working body proved "crucial in the making of the U.S. industrial state in peace and war" (4). If true, then the changing and contradictory nature of so much of this racialist thought-some of Lawrie's sources describe the black body as diseased and inferior, others imagine black physical superiority — and the short lifespan and ineffectual or hamstrung efforts of many of these same agencies become problematic. The book is very strong as an intellectual history of what many Progressives thought about race and labour, but perhaps weaker as a social or political history with convincing claims of more direct cause and effect. Throughout, however, we do see the intellectual frameworks available to policymakers as they addressed race and labour. And there are strong examples of race science limiting black reincorporation into postwar life, such as when FBVE doctors rejected veterans' benefits with reference to supposed pre-existing, natural weaknesses in the African American body (120). So too with Lawrie's discussion of Jamaica as an example to some Progressives of the perils of racial mixing, which surfaces the "scientific" findings that enemies of immigration called upon when passing restrictive legislation (160-165).

The black intelligentsia was forced to swim in these conceptual waters, attempting to rebut statistical models that posed as objective but instead created biological and embodied norms that posited blackness as a deviation from those standards. Like other historians, Lawrie shows W.E.B. DuBois's thought to be particularly nuanced, making early connections between scientific knowledge and racial fantasies and linking the black image in the white mind to the needs of capital. Yet Lawrie also shows how eugenics and segregationist impulses influenced the thought of many black activists, who worried that racial health might be compromised by racial mixing.

Historians' debates about who was or was not a Progressive can be tedious, but Lawrie's broad definition_-almost any reformer of the time seems to qualify as a lowercase "p" progressive-dampens efforts to put the book in more explicit conversation with other scholarship on the movement. Clearly Lawrie sees Progressives as creating racial conceptions and exclusions, and not simply supporting segregation to protect pet projects. But he might have identified and discussed opposing scholarly views. Lawrie briefly explores transnational black movements and empire's power to remake race, but a more binary, black/white racial scheme prevails here as the "postwar emergence of the Caucasian as a racial category reduced the prewar multiplicities of white and near-white races" to "singular tones" (138). It was unclear to this reader how the book interacts with, for example, Joshua Paddison and Stacey L. Smith's scholarship on American citizenship's multiracial boundaries (see Paddi- 
son, American Heathens, 2012; Smith, Freedom's Frontier, 2013).

Despite several references to Franz Boas, Lawrie's written account lacks a coherent discussion of the decline of biologically-based notions of race and the rise of more cultural explanations for group difference. Vile movements such as eugenics can arise, of course, in one area of society precisely as their foundations are being eroded in other spheres, as Lawrie notes. But a brief look toward the Second World War and the long civil rights movement, instead of (or at least in addition to) Lawrie's mention of Black Lives Matter in the book's epilogue, might have helped readers trace some changes in thought and action across the twentieth century without suggesting any inevitable, easy, or irreversible arc toward racial egalitarianism.

In an epilogue, Lawrie's villain, the driving force behind these racist labour taxonomies, appears: it is "the many headed hydra that is American capitalism." He's on safe ground here, for history departments on average lean sharply to the left. And of course he is at least partly correct: that African American bodies have been worked, mocked, and violated by whites for profit and masochistic pleasure is beyond dispute. But Lawrie has surely uncovered lessons that might also make the left uncomfortable. Yesterdays' capital-p Progressives aren't today's lowercase ones, but similarities do exist: a sometimes heavy-handed desire to engineer a frictionless social world springs to mind.

That Lawrie's impressive exploration of the black worker in Progressive thought provokes such criticisms, questions, and musings is further evidence of its importance.

Brian Shott

\section{Joshua Clover, Riot. Strike. Riot: The New Era of Uprisings (London: Verso, 2016). Cloth $\$ 23.95$.}

It seems like there are lots of ways that the have-nots try to stand up for themselves and protect their interests, including seizing food, assembling in public squares, or destroying machinery. Every dramatic event is a story-tragic, heroic, emblematic, or idiosyncratic — as regular people try to make history, albeit in circumstances they did not create. These tales are unpacked, analyzed, and sometimes celebrated in narratives, songs, or poems:

In 1347, crowds seized ships ported in Bristol, appropriating and distributing the grain on board with no concern for profit-one of several food riots scattered across England that spring.

In 1819, 60,000 protesters assembled peacefully at St. Peter's Field in 